Revisla da ANPOLL, n" 4, p. 221-247, jan./jun. 1998

\title{
A CONTRIBUIÇÃO MODERNISTA PARA A FIXAÇÃO DA NORMA LINGÜÍSTICA BRASILEIRA
}

\begin{abstract}
Marli Quadros Leile*
RESUMO: Nesle arligo, procuramos mostrar como a norma brasileira foi reciclada a partir do Modernismo, pelo aproveilamento da língua efetivamente realizada. Oplamos por comentar; especialmente, a melalinguagem de algumas crônicas de Rubem Braga e de dois poemas de Manuel Bandeira, a fim de evidenciar a alitude lingüística desses escritores que fizeram, conscientemente, uso do português brasileiro.

PALAVRAS-CIIAVE: norma lingüística; melalinguagem; purismo lingüístico.

O modernismo representou uma revolução artístico-cultural que deixou conseqüências também na norma lingüística brasileira. $\mathrm{O}$ simples cotejo de textos pré-modernistas, de autores refratários às mudanças lingüísticas introduzidas pelos primeiros modernistas, já poderia ser suficiente para evidenciar a diferença lingüística que começou a se estabelecer depois de 1924. Neste artigo, no entanto, optamos por mostrar por meio da metalinguagem, explícita em crônicas de Rubem Braga e em dois poemas de Manuel Bandeira, como a norma lingüística brasileira foi-se mo-
\end{abstract} dificando.

\section{RUBEM BRAGA E A CRÔNICA}

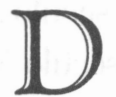

epois de alguns anos passados do "vendaval" que a Semana deArte Moderna representou para a renovação das artes brasileiras, alguns de seus sinais são bem visíveis. Em relação à linguagem,

* Universidade de São Paulo - USP.

Este artigo é uma adaptação de parte de um dos capítulos da tese de doutorado, inédita, O Purismo Lingüístico - suas Manifestações no Brasil, defendida em 1996, pelo Departamento de Lingüística e Semiótica Ceral da Universidade de São Paulo. 
LEITE, Marli Quadros. A contribuição modernista para a fixação da norma lingü̈ística brasileira.

estão presentes na prosa e na poesia de autores, hoje, de grande prestígio, como Carlos Drummond de Andrade, Manuel Bandeira, Guimarães Rosa, Rubem Braga, Fernando Sabino, Paulo Mendes Campos, Graciliano Ramos e Raquel de Queirós para lembrar somente alguns dos mais importantes herdeiros do Modernismo. Faria (1982:67) comprova essa idéia, formulando uma pergunta retórica: "Como negar na poesia de Dummond, de Manuel Bandeira e Augusto Meyer, na prosa de José Lins do Rego e Guimarães Rosa a presença "espiritual' de Mário de Andrade?"

A leveza da linguagem modernista pode ser observada em todos os gêneros literários. É na crônica, no entanto, que se pôde sentir a partir dos anos trinta o reflexo da ruptura modernista com o passadismo. É bem verdade que, como diz Candido (1992:8), desde Bilac, a crônica “já estava brasileira, a ponto de obrigá-lo a amainar a linguagem, a descascá-la dos adjetivos mais retumbantes e das construções raras", porque esse é um gênero em que não cabe a linguagem rebuscada. Na época de Bilac, no entanto, a crônica ainda não era a que temos em nossos dias.

Ainda de acordo com Candido (id.), a definição e consolidação da crônica moderna deu-se no decênio de 1930. Entre outros autores que se afirmaram por essa época (como Carlos Drummond de Andrade, Mário de Andrade e Manuel Bandeira), está Rubem Braga, o único que pode ser considerado cronista por excelência, já que se dedicou (quase) exclusivamente a esse gênero ${ }^{1}$.

Moisés (1994:101-02) faz um breve histórico da crônica, lembrando que na acepção histórica o termo crônica era referente a um tipo de narrativa histórica em que os fatos eram ordenados de acordo com seu acontecimento no tempo, e, como tal, alcançou o ápice no século XII, na França; nesse sentido o termo continuou a ser usado até o século XV. Em outra acepção, de gênero em que se fazia crítica dramática, começou a ser empregado no século XVIII, na França, por meio dos feuilletons, inaugura-

1 O autor publicou, em Recife, 1980, um pequeno livro de poesias, o Livro de Vérsos. Além disso já havia feito parte da Antologia dos Poetas Brasileiros Bissextos Contemporâneos, organizada por Manuel Bandeira, em 19+6. (ARRICUCCI JR., 1988:162). 
dos por Julien-Louis Geoffroy, um professor de retórica que, por esse meio, escrevia artigos, mais tarde reunidos em seis volumes, cujo título é Cours de Literature Dramatique.

Ainda segundo Moisés (op. cit.), no Brasil, os feuilletons deram origem ao folhetim, meio pelo qual desde 1836 escritores (de José de Alencar até Machado de Assis) publicavam contos. A criação e publicação de crônicas tal como a conhecemos hoje teve origem no começo do século, 1900 a 1920, inaugurada por João do Rio e de "larga difusão e aceitação com Rubem Braga, em 1930".

É claro que muitos cronistas, desde a década de 30, são dignos representantes do gênero no Brasil. No entanto, tomemos Rubem Braga não só por ter sido uns dos primeiros divulgadores, e criadores, desse estilo literário que pode até ser chamado brasileiro, mas também porque é o único que se dedicou completamente à crônica e por meio dela influenciou a norma lingüística brasileira.

Como já acentuaram os críticos literários, Antônio Cândido e Massaud Moisés, já citados, a crônica é um tipo de literatura "de jornal", que não foi feita para durar, e que fala das coisas miúdas do dia-a-dia. Por isso mesmo, de linguagem leve, mais próxima da realidade lingüística do país. O assunto e a linguagem, aliados, fazem o sucesso da crônica, especialmente no Brasil, país em que há um imenso déficit educacional, e onde a literatura densa que demanda "reflexão e inteligência crítica" para a sua compreensão não encontra espaço na massa leitora. Esse espaço é da crônica.

Moisés (1994:119) afirmou que a crônica, mesmo publicada em livro, encontra rapidamente a "senescência precoce", e diz: "Machado de Assis, se ressuscitasse em nossos dias, veria, entre cético e melancólico que suas crônicas reunidas em volume não conhecem o milagre da reedição". Esse é um ponto que, hoje, merece revisão. Em primeiro lugar porque as crônicas de Machado de Assis foram reeditadas, por exemplo, pela Folha de São Paulo e Editora Ática, em 1992. Em segundo, porque há, desde a 
LEITE, Marli Quadros. A contribuição modernista para a fixação da norma lingüística brasileira.

década de 70, grande circulação de crônicas em livros, quer paradidáticos - como a coleção Para Costar de Ler, um sucesso editorial - ou não, como os volumes de Rubem Braga, que têm muitas reedições². Em verdade, há muitos outros autores que tiveram seus volumes de crônicas reeditados, como Carlos Drummond de Andrade c Fernando Sabino.

Desse modo, não há como negar a importância da crônica para a literatura e, principalmente, para a língua do Brasil ${ }^{3}$.

A maior vitória do Modernismo foi, sem dúvida, relativa à linguagem. Como afirmou Peregrino Júnior, esse movimento

"liberlou os escritores brasileiros de uma imemorial e voluntária subordinação aos cânones clássicos de Porlugal, permilindo-Ihes adotar uma linguagem mais livre, mais solla, mais nalural, de inspiração regional e popular, o que representou sem dúvida um enriquecimento e uma liberlação para a nossa língua literária, tornando realidade aquilo que os românticos, Alencar à frente, tentaram fazer em pura perda" (Coutinho, 1976:289).

Assim, Coutinho (ib.) diz que o Modernismo procedeu a uma purificação da língua no Brasil. A esse propósito, o autor cita a crônica $O$ Trabalho do Modernismo, em que Rubem Braga se refere à "liberação dos fantasmas que povoaram a mente dos nossos escritores, criados pela subordinação aos cânones lusos e entravando a sua liberdade expressional".

\title{
0 Trabalho do Modernismo
}

\begin{abstract}
Rubem Braga ${ }^{+}$
Pensemos nos pronomes. Até o Modernismo quem escrevia em língua portuguesa tinha um fantasma pela frente: os pronomes. Uma das preocupações do escritor era colocá-los bem. Preocupação
\end{abstract}

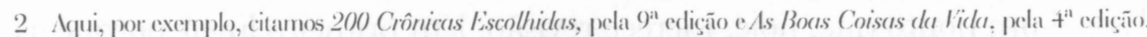

3 Sobre a predominância da crônica na literatura do Brasil, Décio Pignatari alirmou recentemente: "() Brasil não tem mais escritores, só cronistas. A crônica matou a prosa brasileira. Todo mundo cpuer ser best seller: todo mundo escreve crônica". (Folha de S. Prulo, llustrada, t, 31 de maio de 1996).

+ Crônica publicada em 28 de junho de 19+2, no Diário de Nolícias, Rio de danciro. 
estéril para o escritor, porque desviava a sua atenção para um problema que não envolvia o me-

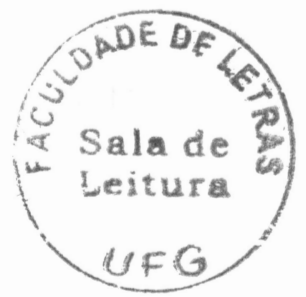
nor interesse estético, um problema infecundo. E os modernistas? Aparentemente eles se libertaram dessa preocupação, mas apenas, aparentemente. Na realidade o que eles fizeram foi libertar disso os pós-modernistas. 'Tanto quanto o acadêmico, o modernista foi atrapalhado pelos pronomes. Preocupou-se em colocá-los mal - de acordo com a gramática portuguesa. Teve o trabalho de colocá-los à mancira brasileira, ou às maneiras brasileiras, $\mathrm{c}$ ainda de inventar meios de colocá-los. De qualquer modo preocupou-se fortemente com os pronomes. Em certas frases de escritores acadêmicos vemos um pronome, situado de acordo com as melhores regras, que estraga a frase, incomoda o leitor, dói. Em frase de escritores modernistas vemos pronomes tão abusiva e deliberadamente errados que também incomodam, que também dão na vista. Para reagir contra a linguagem de colarinho duro muitos modernistas desceram até a linguagem cafajeste. Lutando contra uma falsa dignidade da língua escreveram, às vezes, uma linguagem sem dignidade.

Ora, o pós-modernista teve esta vantagem: desconheceu os pronomes. Foi escrevendo os pronomes da maneira que lhe pareceu mais fácil, sem reparar como escrevia, sem se preocupar se estava certo ou crrado. O pronome para ele ficou sendo um elemento qualquer da oração como o 
advérbio por exemplo. Enfim: o pós-modernista não teve mais o problema dos pronomes. A língua escrita antes do Modernismo era incômoda e desconfortável. Acontecia que, para escrever com simplicidade, um escritor, que tinha a obrigação de ser correto, enfrentava problemas complicadíssimos de estilo. A maioria preferia escrever sem simplicidade. Que fizeram os modernistas? Reagindo contra a linguagem lusitana se agarraram aos barbarismos. Assim como os outros se preocupavam em embelezar a frase com palavrões clássicos e às vezes arcaicos, os modernistas se preocuparam em recheá-la de brasileirismos e palavras plebéias. Abriram as porteiras da língua, e ficaram atrapalhados com a invasão. Fizeram como crianças que, tendo aprendido algumas palavras feias, as repetem a todo momento, embora sem oportunidade, para mostrar que sabem essas palavras e que podem dizê-las. Fizeram demonstração. Demonstração e em muitos casos exibicionismo, abuso deliberado, ostentação novo-rica da língua que tinham ido buscar na boca do povo - às vezes através de livros de folclore - para meter na língua escrita. Naturalmente neste detalhe como em outros o mal variou de acordo com os temperamentos pessoais. Em muitos casos chegou a um preciosismo populista mais precioso que qualquer preciosismo acadêmico. Assim fazendo os modernistas fizeram bem... aos que vieram depois. Assim mesmo fizeram mal, porque se preocupando tanto 
Revista da ANP()LL, n" 4, p. 221-247, jan./jun. 1998

com a língua, com o instrumento de trabalho, prejudicaram o próprio trabalho. Já os pós-modernistas não precisaram mais se preocupar mais com casticismos nem com barbarismos. Quando começaram a escrever foram escrevendo, pensando apenas em dizer o que queriam dizer, em dar o seu recado. Foram escrevendo na língua que thes pareceu mais cômoda, mais fácil de escrever c de ser entendida.(Coutinho, 1976:290)

Nesse texto, Rubem Braga caracteriza muito bem o movimento lingüístico modernista e pós-modernista brasilciro. Primeiro, o exagero próprio das revoluções, a ruptura, o "abre-alas" para a prática da língua portuguesa do Brasil. Depois, a acomodação e com ela a retomada de posições anteriores à "revolução", talvez, até mesmo ortodoxas. No texto de Rubem Braga isso fica patente na crítica que faz ao exagero verbal modernista, na utilização desenfreada de "brasilcirismos" e "populismos". O certo é que os escritores que trabalharam depois do momento da ruptura modernista, como o próprio Rubem Braga, encontraram uma situação lingüística cômoda para escrever o que queriam e do modo mais fácil, já que cram permitidos alguns usos mais próximos dos praticados no Brasil.

Disso não se pode concluir, entretanto, que a permissividade estivesse instalada. Não. Nessa fase, atendeu-se também às normas gramaticais, e a liberdade linguiística era mesmo relativa à ordem dos termos na frase e ao estilo. A frase passou a ter ordem predominantemente direta e, de longa e labiríntica, com predomínio da subordinação, passou a curta c objetiva, compondo período de duas ou três orações. Além disso, o léxico deixou de ser precioso, extremamente culto, e passou a comum, mais próximo da realidade lingüística brasileira. Passou a haver, inclusive, incorporação de palavras tidas como galicismos, rejcitadas até o Modernismo.

Em relação à gramática, o contraste maior com a norma portuguesa ficou por conta realmente do uso dos pronomes, como está explicado na 
LEITE, Marli Quadros. A contribuição modernista para a fixação da norma lingü̈istica brasileira.

crônica citada. Também há outros usos próprios da norma brasileira. Por exemplo, a utilização predominante do gerúndio, em vez do infinitivo; algumas regências verbais, como a dos verbos assistir, visar, obedecer, responder todos usados com complemento direto e o uso de algumas preposições, como em, em vez de $a$, como ć norma cm Portugal.

Algumas dessas renovações são facilmente encontradas nos textos de Rubem Braga. A linguagem é cuidada, havendo até, em alguns pontos, usos tradicionais, muito distantes da norma objetiva. Na crônica citada abaixo, por exemplo, cle emprega um pretérito mais-que-perfeito na frase: "Na véspera o filho dissera ao pai que o chefe da repartição estava docnte". Mais adiante, mostra-se preocupado com a regra de colocação do numeral depois do pronome indefinido todos, fato que foi objeto de metalinguagem, o que prova a preocupação do autor com a claborção lingüística. Lá está cm "Coração de Mãe":

"- E a senhora também! Pensa que cu estou disposta a viver ouvindo desaforos? A senhora precisa deixar de ser...

Depois do verbo 'ser' veio uma palavra que elevou dona Rosalina ao êxtase da fúria. As moças foram empolgadas $\mathrm{em}$ um redemoinho de tapas c pontapés escada abaixo, ao mesmo tempo $\mathrm{cm}$ que dona Rosalina berrava:

- Fora! Para fora daqui, todas duas!

("Todas duas é galicismo, conforme algum tempo observou um leitor da Cramática Expositiva Superior de Eduardo Carlos Pereira, residente naquela pensão, em palestra com alguns amigos.) Outras palavras foram gritadas em tão puro $\mathrm{e}$ rude vernáculo que tẹtarci traduzi-las assim:

— Passem já! Vão fazer isso assim assim, vão 
Revista da ANPOLL, n" 4, p. 221-247, jan./jun. 1998

para o diabo que as carregue, suas isso assim assim! Não ponham mais os pés na minha casa! (O leitor inteligente substituirá as expressões 'isso assim assim' pelos termos convenientes; a leitora inteligente não deve substituir nada para não ficar com vergonha.) (Crifamos) (200 Crônicas:19)

Pereira (1945:326) não accita nem o uso de todas duas nem de todas as duas, recomenda o vernáculo os dois ou $\operatorname{ambos}^{5}$. Mas o texto de Rubem Braga é de 1938 e a preocupação com os galicismos já não cra tão forte. No entanto, ainda se manifestava até como demonstração do saber lingüístico, atitude que nunca desaparece: ou está presente no próprio uso, ou em comentários sobre $\mathrm{ele}^{6}$. A citação é significativa não somente pela revelação do purismo ortodoxo explícito, confirmado até na expressão puro e rude vernáculo, que mesmo $\mathrm{cm}$ sentido anticonvencional marcou presença c o autor a registrou. Também fica patente nesse trecho o comportamento conservador do autor, próprio da época, na sugestão do narrador aos "cavalheiros", que conhecem a realidade da vida e nada thes cai mal. Para as "damas", que são finas e puras e tudo lhes pode atingir; sugere outra interpretação acerca dos palavrões travestidos no "isso assim assim", usados em substituição ao xingamento da personagem.

Precisamos registrar que, se o instrumento de trabalho é a palavra, há sempre alguma preocupação com o seu uso. Até mesmo a crônica, em que há uma "linguagem volátil", como diz Arrigucci jr: (1988:5), apresenta marcas de elaboração lingüística. E aqui não falamos daquela pre-

5 O texto normativo contemporâneo traz a recomendação de não se usar o artigo antes do numeral em aposiçīo a lodos, se o substantivo a que se refere estiver ausente, mas, se o substantivo presente, o artigo é olbrigatório (cf. Cumba \& (intra, 1985:224).

6 De acordo com Coseriu (1979:120), a língua ć um saber que se adquire antes da norma. O conhecimento desta implica um domínio de maior grau de "cultura". É exatamente a demonstragão desse saber (da língua ou da norma) que produz a metalinguagem. 
LEITE, Marli Quadros. A contribuição modernista para a fixação da norma lingüística brasileira.

ocupação difícil com a simplicidade, da qual Rubem Braga fala no texto "O pavão" ("Eu considerci que este é o luxo do grande artista, atingir" o máximo de matizes com o mínimo de elementos"), mas da preocupação purista de continuar dentro da tradição, mesmo quando o ideal não é estar completamente de braços dados com ela. Desse modo, surgem comentários como o da crônica "Faço Questão do Córrego":

"A esta altura vocês já devem estar desconfiados que hoje não estou nada bom. E têm razão: confesso humildemente que estou com a chamada cachorra. A expressão é antiga, c não é bonita; mas cu é que não vou procurar outra." (1s Boas Coisas:86)

O tipo de texto autoriza o uso de uma expressão como "estou com a chamada cachorra", até porque é da voz do povo. Mas o escritor; pelo uso do particípio chamada, cria o efeito de sentido de distanciamento, a idéia da indeterminação discursiva, acerca da voz que considera vulgar aquele estado depressivo, conhecido como "a cachorra". Por meio de tal recurso sugere não ser aquela a voz do autor, que protege a sua face atrás do chamada cachorra, deixando implícito que ele não diz aquilo, mas o outro, o povo.

Assim mesmo (ou por isso mesmo), registra o scu juízo de valor sobre a expressão empregada. $\mathrm{O}$ autor usa a expressão por uma razão qualquer, talvez até para que servisse como um submotivo para a crônica, que se foi construindo como uma colcha de retalhos, com um tópico daqui e outro dali, como está confessado nesse mesmo texto, desde o início: "Estou fraco de idéias no momento. (...) Às vezes a gente finge que trabalha; o leitor lê a crônica c no fim chega à conclusão de que não temos assunto. (...) A grande vantagem do leitor é que ele pode largar a crônica no meio, ou no começo, e eu tenho de ir tocando com ela, mesmo sentindo que estou 
falando sozinho. (...) Que me importa: tenho de escrever, vivo disso. Mal."

No texto "Rita Lee" faz metalinguagem com seu prosaísmo, a fim de deixá-lo passar. Usa-a para, pela autocrítica, autorizar uma dicção que considerou vulgar, trivial. Assim diz:

(...) - primeiro a mão com um comprido indicador apontando as gambiarras... perdão, eu disse gambiarras? então está dito: gambiarras; ponhamos Rita Gambiarras I_ec, coração de magra leoa faminta de luzes.

É doce escrever bobagens assim, ela |Rita Iـec| inspira isso."

Também em “Achei Melhor não Reclamar”, surge a metalinguagem - pretexto para a crônica. Fica evidente que o autor não tem intenção de escrever sobre o uso da língua. Ao contrário, depois de escrever aleatoriamente, percebe certa irregularidade na linguagem e faz dela mais um assunto da crônica, aproveitando o tema inesperado, que, afinal, registra os passos da claboração do texto. É o que está posto em:

"Da última vez que falei convosco eu estava parado na Praça da República, no Rio de Janciro, esperando condução em vão, depois de sair da Rádio Ministério da Educação. ̃̃o, ão, quanto ão. Aliás, eu podia ter começado a crônica de antes. Eu atravessara o Campo de Santana depois de vir da Avenida Passos pela Senhor dos Passos a pé (a passo). Qual, isso é sinal de cansaço mental, escrever assim rimando, tropeçando em palavras, palavra.

Reajo, vou escrever direito, contar o que tenho para contar. Pensando bem, é coisa pouca ou 
LEITE, Marli Quardros. A contribuição moderinista para a fixação da norma lingüística brasileira.

nada. Eu perambulava (...)" (As Boas Coisas:164-65)

Segundo Rubem Braga, a exigência com o uso da linguagem deve obedecer a certos critérios de "dignidade c limpeza", como está relatado na crônica "Por quem os Sinos Bimbalham". Para falar dessa exigência, que como sabemos é, de acordo com o autor, a simplicidade, cle nos conta o caso de dois escritores de última hora. Um homem, amigo do diretor de um semanário, Joel Silveira, que há muito prometia a este um artigo, sobre economia ou política. E o de uma mulher, "muito recomendada", de quem publicariam uma crônica.

Depois de longo tempo de espera, o diretor do semanário recebe o artigo do amigo e grita ferozmente:

"- Veja se é possível publicar isto! Lecia só as três primeiras palavras̀: você não conseguirá chegar até a quarta palavra, a linotipo vai engasgar na hora de compor isso!

Olhei - mas Joel já bradava para toda a redação ouvir, aquele começo genial: 'Tirante, é óbvio, ...' $\mathrm{E}$ indignado:

- A gente tropica na primeira vírgula, passa por cima desse óbvio, bate com a cabeça na segunda, morre!" (As Boas Coisas:177)

O texto da mulher não tem melhor sorte. Depois que o secretário da redação o tem cm mãos c o pega para ler, sua expressão "murcha", porque lá está escrito:

"Natal! Natal! Bimbalham os sinos..." (Grifamos) (As Boas Coisas:178) 
Nos dois casos, a crítica do cronista recai sobre a vulgaridade, os clichês das expressões usadas pelos autores neófitos. Atrás daquelas palavras (tirante, óbvio, bimbalham) estava escondida a "pompa" c a grandiloqüiência rejeitada pelos modernistas, com Rubem Braga à frente, na crônica. Esse tipo de linguagem não seria admissível depois que o novo modo de escrever já estava solidificado.

Quanto à sintaxe, Rubem Braga segue o uso brasileiro em rèlação, principalmente, à ordem da frase e colocação de pronomes, embora sem exageros. Começo de frase com pronome oblíquo é muito raro; no geral esses pronomes em início de frase só aparecem no discurso "do outro" c quando surgem no seu próprio, a frase está, quase sempre, entre aspas para marcar a intenção de reproduzir a oralidade. Em "A Conspiração dos Outros" temos um exemplo em que a fala do narrador está $\mathrm{em}$ discurso direto, com um me no início da frase, mas entre aspas:

"Ontem tive um dia mau, um desses dias $\mathrm{cm}$ que a gente tem vontade de ir até o acroporto, puxar as notas que tem no bolso e os níqueis e dizer em qualquer balcão de companhia: 'Me dá isso de passagem'." (As Boas Coisas:124)

Quanto à colocação dos pronomes átonos, podemos considerar que Rubem Braga segue a norma brasileira, sem, no entanto, abandonar completamente alguns princípios tradicionais. Isso não significa, porém, que em seus textos não apareça, vez por outra, um pronome em início de oração e, nesses casos, não podemos dizer se por inadvertência ou intenção. Mas podemos, mais uma vez, dizer que é difícil ao escritor desvencilhar-se de scus hábitos lingüísticos cotidianos. Vejamos algumas passagens que trazem o uso de pronomes.

Os pronomes enclíticos aos verbos iniciadores de período gramatical em geral, estão de acordo com a prescrição tradicional, como os dos exemplos seguintes: 
LEITE, Marli Quadros. A contribuição modernista para a fixação da norma lingüística brasileira.

"Mandou-me um bilhete com letra meio trêmula." (200 Crônicas:131)

"Contou-me por exemplo que seu pai, homem de 80 anos, (que se lembra muito bem do tempo em que centenas de burros enchiam o largo do Arouche), seu pai, que mora na Quarta Parada, vai toda semana comprar carne em Mogi da Cruzes, onde é mais barata e bem mais servida." (200) Crônicas:142)

Sinto-me bem, oferecendo-me este copo, na casa silenciosa, nessa noite de rua quicta." (200 Crônicas:155)

A regra não é seguida, porém, neste caso $\mathrm{em}$ que o pronome abre o período, já que o advérbio (que poderia servir de palavra atrativa) está isolado por pausa. Aqui está uma construção tipicamente brasileira:

"Enfim, nos conformamos - mesmo porque não
temos luvas, nem garçom, nem chá." (200
Crônicas:95)

Essa construção pode ainda causar certa dúvida porque é o pronome precedido de advérbio, mesmo que seguido de clara pausa, inclusive marcada por vírgula. No entanto, o exemplo que segue é inequívoco: Rubem Braga começa um parágrafo com o pronome átono:

"Me lembrei de uma história de Lúcio Cardoso, que trabalhava na Agência Nacional: Um $\operatorname{dia}(. .) ".(200$ Crônicas:168)

À primeira vista, o "me" da frase abaixo parece estar $\mathrm{cm}$ desconformidade com a regra, o que não é verdade porque, embora esteja 
Revisla da ANPOLL, n" 4, p. 221-247, jan./jun. 1998

iniciando período, faz parte de uma oração intercalada c tal fato autoriza o uso, conforme explica Rocha Iima (1969:474).

\begin{abstract}
"Não, não cra casado - morava com os pais, que sustentava com scu trabalho. 'Aliás - me disse subitamente, com um brilho nos olhos e as mãos trêmulas como quem toma coragem para fazer uma confissão sensacional - aliás esse foi o primeiro ideal que me propus a realizar na vida." (200 Crônicas: 142 )
\end{abstract}

A norma tradicional também é observada nos casos em que o autor coloca enclíticos os pronomes aos verbos antecedidos de sujeito, pronomes ou substantivos, que não sejam de significação negativa (Rocha lima, op. cit.:475):
"Aconteceu por exemplo, senhor, que outro dia um velho amigo deu-me o prazer de me fazer uma visita." (200 Crônicas:143)

O próximo exemplo traz um uso característico do português do Brasil: o pronome oblíquo solto entre os verbos de uma perífrase. No caso da perífrase com gerúndio, Rocha lima (op. cit.:480) explica que são três as colocações admissíveis do clítico: 1. ênclise ao gerúndio; 2. ênclise ao auxiliar; 3. próclise ao auxiliar. Conclui-se, então, ser posição inadmissível, do ponto de vista tradicional, prescritivo, a preferida no Brasil: próclise ao gerúndio, como Rubem Braga o fez nos exemplos a seguir postos:

"Minha empregada, Mme. Thérèse, que já ia se
conformando em ser chamada de dona Teresa,
caiu doente." (200 Crônicas:131)
"É noite de Natal, e estou sozinho na casa de 
LEITE, Marli Quadros. A contribuição modernista para a fixação da norma lingüiística brasileira.

um amigo, que foi para a fazenda. Mais tarde talvez saia. Mas vou me deixando ficar sozinho, numa confortável melancolia, na casa quicta e cômoda." (200 Crônicas:155)

O mesmo caso ocorre com o pronome intermédio entre um auxiliar e um infinitivo, sendo que nesse caso a norma autoriza uma quarta opção que é a próclise ou ênclise ao infinitivo precedido de preposição. Mas a próclise ao infinitivo não precedido de preposição é ainda proibida. Também nesse caso Rubem Braga prefere $o$ uso brasileiro à norma lusitana:

"Desembrulho a garrafa que um amigo teve a lembrança de me mandar ontem; vou lá dentro, abro a geladeira, preparo um uísque, c venho me sentar no jardinzinho, perto das folhagens úmidas." (200 Crônicas:155)

Outro tema objeto das discussões na fase pré-modernista, mas que Rubem Braga usou ao estilo brasileiro, foi a ordem dos termos na frase. As frases são curtas, o léxico comum, ligado à vida do dia-a-dia. Um trecho da crônica "A Empregada do Sr. Heitor" pode demonstrar bem essas características:

Era noitinha em Vila Isabel... As famílias jantavam. Os que ainda nạ̃o haviam jantado chegavam nos ônibus e nos bondes. Chegavam com aquela cara típica de quem vem da cidade. Os homens que voltam do trabalho da cidade. As mulheres que voltam das compras na cidade. Caras de bondes, caras de ônibus. As mulheres trazem as bolsas, os homens trazem os vespertinos. Cada um entrará em sua casa. Se o homem tiver um cachorro, o cachorro o receberá no 
portãozinho, batendo o rabo. Se o homem tiver filhos, os filhos o receberão batendo palmas. Ele dará um beijinho mole na testa da mulher. A mulher mandará a empregada por a janta, e perguntará se ele quer tomar banho. Se houver rádio, o rádio será ligado. () rádio tocará um fox. Ouvindo o fox, o homem pensará na prestação do rádio, a mulher pensará em outra besteira idêntica. O homem dirá à empregada para dar comida às crianças. A mulher dirá que as crianças já comeram. A empregada servirá a mesa. Depois lavará os pratos. Depois irá para o portão. (...) (200 Crônicas:3)

Em todo o trecho não encontramos nenhum período com mais de três orações e nenhum termo sintático na ordem inversa. A crônica flui simples e rápida lembrando o sentido monótono da vida das personagens que marcham pelo cotidiano, repetindo a vida-clichê urbana. A linguagem é expressiva, mas o toque literário nasce, por paradoxal que pareça, da organização simples das frases na abordagem do assunto tão simples e comum que é a vida de todo mundo que vive naquele lugar. O léxico não foge à regra e sai de dentro de todas as casas de família como aquela: os patrões chegando do trabalho e das compras, a janta na mesa, os pratos lavados c o portão. É também o léxico que, ao mesmo tempo em que denuncia a mesmice da vida, denuncia os hábitos, e objetos a eles relacionados, antigos. Aí vemos o bonde, o vespertino, o rádio (ao chegar em casa, hoje, liga-se a TV) e o fox. Afora isso, embora seja uma crônica de fevereiro de 1935, ainda é atual em qualquer subúrbio de cidade grande.

Para estabelecer o confronto entre a norma brasileira e a portuguesa, é preciso registrar que a ordem inversa da frase consistia um princípio da sintaxe lusitana que vigorou no Brasil até o Modernismo. A dispọsição 
LEITE, Mauli Quadros. A contribuição modernista para a fixação da norma lingüïstica brasileira.

dos termos na ordem direta era galicismo, pois constituía a norma francesa. Mário Barreto, por exemplo, reagindo à crítica de um consulente, quanto às freqüentes inversões que praticou nos Novíssimos Estudos disse:

"Não vou com certa tendência que atualmente se observa, e a meu parecer funesta, para a introdução em nosso idioma da ordem direta da frase francesa, o período do agente, verbo e complemento, - estrutura frascológica de uma pobreza e monotonia supremas - em substituição da construção indireta que ilustraram tão gloriosamente os nossos antepassados." (Barreto, 1954:42)

Ainda para abonar sua posição, Barreto (id. ib.) transcreve trecho de A. F. de Castilho, escritor português, "mestre no traslado da língua francesa para português limpo de galicismos, quer na palavra, quer no boleio da frase". E, assim, afirma Castilho:

"Uma diferença característica dos períodos, francês e português, é esta: que o francês se adstringe, quase sem exceção, à chamada ordem gramatical, colocando primeiro o sujeito, depois o verbo, por último o complemento, quer este seja atributivo, quer objetivo; isto é, ou designe predicado ou paciente, segundo a natureza neutra ou transitiva do mesmo verbo. O português quanto mais genuíno, tanto mais propende para por primeiro o verbo, e depois o seu agente; e se constantemente o não faz, é porque algumas vezes lho embarga a suprema lei da clareza, outras a da harmonia." 
Como nos textos de Rubem Braga não é regra a inversão de termos, ao contrário, o é a ordem direta, podemos afirmar que nesse ponto o autor segue a norma brasileira, já propugnada pelos modernistas, mas naquele tempo ainda envolta pelo clima da novidade, do exagero da ruptura. Os galicismos morfológicos e sintáticos e a colocação pronomimal ocuparam o centro de atenção dos críticos e dos gramáticos, e muita metalinguagem se produziu sobre isso. Mas a ordem dos termos na frase, de que não se fala tanto, é fator decisivo na fixação da norma brasileira. Afinal, um dos fortes motivos da clareza da frase pós-modernista é esse fato.

Não queremos dizer com isso que a ordem direta não tenha sido anteriormente praticada no Brasil, mas que a sua consolidação ocorreu com a primeira geração pós movimento modernista, da qual faz parte Rubem Braga. Na voz de Antônio Candido (1992:9) encontramos respaldo para essa afirmativa quando ele diz que na crônica, desde Bilac, não havia lugar para a linguagem rebuscada, de vocabulário opulento e com inversões freqüentes. O autor afirma que a crônica brasileira, também depois de 1930, já começava a apresentar um estilo próprio, amalgamando a tradição e a inovação da prosa modernista. Diz cle:

"Tanto em Drummond quanto nele |Rubem Braga| observamos um traço que não é raro na crônica brasileira: no estilo, a confluência da tradição, digamos clássica, com a prosa modernista. Essa fórmula foi bem manipulada em Minas (onde Rubem Braga viveu alguns anos decisivos de sua vida); e dela se beneficiaram os que surgiram nos anos 40 e 50, como Fernando Sabino e Paulo Mendes Campos. É como se (imaginemos) a linguagem seca e límpida de Manuel Bandeira, coloquial e corretíssima, se misturasse ao ritmo falado de Mário de Andrade, com uma pi- 
LEITE, Marli Quadros. A contribuição modernista pa a fixação da norma lingïística brasileira.

tada do arcaísmo programado pelos minciros." (Id.)

O estilo labiríntico de frase, desde início do século 20, vinha perdenddo espaço no Brasil, até mesmo com Rui Barbosa. Lacombe (1966:16) anota com precisão que o próprio Rui Barbosa, a certa altura da vida, transformou seu estilo, abandonando os longos períodos e passando a adotar outros curtos, precisos e claros. Assim diz I Lacombe:

"Além da oratória parlamentar, Rui Barbosa desenvolve três atividades literárias: a tribuna popular; a oratória forense c o jornalismo político. Em todas a transformação de seu estilo foi paralela. (...)

Comparem-se, por outro lado, os períodos do discurso do Colégio Anchicta com os primeiros da Campanha Abolicionista. A imponência, o ímpeto, a sonoridade são as mesmas. Como se ganhou, porém, com a simplificação das linhas, com a redução dos períodos, mais curtos e mais claros!" (Ib.)

O autor compara dois trechos de Rui para comprovar a diferença de estilo. Um do final do século XIX, 1893, e o outro de 1915. No do primeiro período, temos uma frase tão longa que ao chegarmos ao final, quase não nos recordamos da primcira proposição:

"Aos primeiros sorrisos longínquos da minha terra na curva azul de sua enseada o vapor me aproximava rapidamente destas doces plagas, onde minha mãe me embalou o primciro e meus fi- 
Ihos me velarão, talvez, o último sono, vendo pendurar-se do céu e estremecer para mim o ninho onde cantou Castro Alves, verde ninho murmuroso de eterna poesia debruçado entre as ondas e os astros, parecia-me que a saudade, amado fantasma evocado pelo coração, me estendia os braços de toda a parte no longo amplexo do horizonte." (Barbosa, 1966:150)

E no segundo lemos frases curtas e ágcis que dão um efeito especial ao texto, deixando em evidência o contraste que o autor almeja fixar:

"O sertão não conhece o mar. O mar não conhece o sertão. Não se tocam. Não se vêem. Não se buscam. Mas há em ambos a mesma grandeza, a mesma imponência, a mesma inescrutabilidade. Sobre um e outro se estende esse mesmo enigma das majestades indecifráveis. De um c outro ressalta a mesma expressão de encrgia, força e poder a que não se resiste." (Barbosa, 1966:17)

A metalinguagem produzida sobre o português do Brasil e a própria língua escrita $\mathrm{em}$ uso mostram que a norma lingüística brasileira solidificada depois do Modernismo já estava mais próxima da realidade lingüística do Brasil. No cntanto, a luta pela incorporação definitiva dessa norma na gramática tradicional continua, c até hoje nos deparamos com o "discurso da norma", havendo de um lado os defensores de usos conservadores e, de outro, os defensores das inovações.

Observamos, nessa fase, que ao lado do purismo ortodoxo, que reclama sempre a presença da diacronia na sincronia, passa a vigorar o purismo nacionalista, alçado à língua literária por meio da crônica. Essa age no sentido de preservar a norma linguiística brasileira. Diferentemente do que 
LEITE, Marli Quadros. A contribuição modernista para a fixação da norma lingüística brasileira.

aconteccu na primeira fase modernista, em que o nacionalismo era o cxagcro do uso brasileiro, o purismo nacionalista pós-modernista é o equilíbrio: rejeitam-se palavras e expressões que não fazem parte da norma brasilcira.

\section{MANUEL BANDEIRA: NOVOS CAMINHOS PARA A LÍNGUA DO BRASIL.}

No Modernismo, a poesia foi também meio para se externarem revoltas contra o artificialismo da norma lingüística vigente até o primeiro quartel do século XX. Manuel Bandeira bradou contra o status quo lingüístico que prevalecia então, quando clamou pelo emprego da linguagem natural, livre das regras morfossintáticas e do rigor léxico, voltados para a norma curopéia. Bandeira é antipurista não somente em relação à ortodoxia da linguagem, mas também $\mathrm{cm}$ relação à forma $\mathrm{e}$ ao conteúdo do texto literário. Por outro lado, podemos dizer que é um purista nacionalista, caracterizado pela extrema valorização da língua e da literatura nacional.

Em "Poćtica" vemos a força dos versos de Bandeira, funcionando como verdadeiros argumentos em prol da norma brasileira:

\section{Poética}

Estou fato do lirismo comedido

do lirismo bem comportado.

Do lirismo funcionário público com livro de ponto expediente Iprotocolo c manifestações de apreço ao Sr. Idiretor

Estou farto do lirismo que pára e vai averiguar no dicionário lo cunho vernáculo de um vocábulo 
Revista da ANPOLL, n 4, p. 221-247, jan./jun. 1998

\section{Abaixo os puristas}

Todas as palavras sobretudo os barbarismos universais

Todas as construções sobretudo as sintaxes de exceção

Todos os ritmos sobretudo os inumeráveis

Estou farto do lirismo namorador

Político

Raquítico

Sifilítico

De todo lirismo que capitula ao que quer que seja fora de si

|mesmo.

De resto não é lirismo

Será contabilidade tabela de co-senos secretário do amante exemplar lcom cem modelos de cartas e as diferentes [manciras de agradar às mulheres, etc.

Quero antes o lirismo dos loucos

O lirismo dos bêbedos

O lirismo difícil e pugente dos bêbedos

O lirismo dos clowns de Shakespeare

- Não quero mais saber do lirismo que não é libertação.

(Bandeira, 1986:207) (Grifamos)

Outra crítica de Manuel Bandeira à situação lingüística brasileira está gravada cm "Evocação do Recife". Nesse poema há a intuição de Bandeira sobre a historicidade da língua, pois diz que o que fazemos no Brasil é "macaquear a sintaxe lusíada". Em outros termos, a norma só é integralmente praticada por aqueles que a criam. Se se quer praticar a norma de Portugal no Brasil haverá sempre um déficit do uso em relação a essa norma, ou melhor, há sempre a predominância da norma local, produto da língua efetivamente realizada. 
LEITE, Marli Quadros. A conlribuição modernista pu a fixação da norma lingüística brasileira.

O poema "Evocação do Recife" traz referência, importante, pela qual se comprova que a intenção dos modernistas era fazer o alinhamento da norma brasileira, a partir da observação direta da língua em uso. Os versos de Bandeira aos quais nos referimos são os seguintes:

(...)

"A vida não me chegava pelos jornais nem pelos livros

Vinha da boca do povo na língua errada do povo

Língua certa do povo

Porque ele é que fala gostoso o português do Brasil

$$
\begin{aligned}
& \text { Ao passo que nós } \\
& \text { O que fazemos } \\
& \text { É macaquear a sintaxe lusíada }
\end{aligned}
$$

A vida com uma porção de coisas que cu não entendia bem (...)

$$
\text { (Op. cit., p. 213) }
$$

A conscientização de que a norma brasileira era mesmo diferente da portuguesa foi-se solidificando, cada vez mais. Como Rubem Braga, na esteira de Manuel Bandeira e de outros modernistas, muitos escritores foram, aos poucos, adotando o modo brasileiro de escrever, em termos de léxico e gramática e, desse modo, foi-se fixando uma norma lingüística para a língua escrita do Brasil, menos distante da língua efetivamente praticada no país ${ }^{?}$.

7 Adoção no sentido coseriano: "aquisição de uma forma nova, duma variante, dum modo de selecionar; cm vista de atos futuros." COSERIU (1979:72) 


\section{CONSIDERACOÕES FINAIS}

Desse modo, podemos verificar que na fase modernista a linguagem recortada ao estilo lusitano estava enfraquecida. Também, os exageros dos modernistas de primeira hora não tinham mais sentido, pois já se podia praticar uma linguagem mais próxima da realidade brasileira, sem as pressões dos que queriam a todo custo manter a norma de Portugal no Brasil. Nessa fase, o discurso do narrador também já apresentava linguagem mais próxima da realidade lingüística brasileira. Isso primeiro apareceu, por exemplo, nos romances de Graciliano Ramos e José I Lins do Rego e constituiu o ponto de culminância, sob o ponto de vista linguístico, do pósmodernismo. Foi o período da solidificação da norma brasileira e, pode-se dizer, o início da prática de um purismo que começou a funcionar com base nessa norma, ainda não codificada, mas óbvia, por exemplo, no léxico e na sintaxe em ordem direta ${ }^{8}$.

Nessa fase, a língua se mostra muito diferente daquela praticada do começo do século até 1930, aproximadamente. As pressões da tradição clássica estavam mais atenuadas, embora ainda presentes. A diferença agora cra a existência de uma tradição brasileira com força para se impor. Desse modo, podemos considerar mudado o panorama lingüístico brasileiro, pois o espaço antes ocupado pelas discussões acerca do problema da diferenciação lingüística Brasil/Portugal passou a ser preenchido pelas polêmicas sobre a relação língua/socicdade e os problemas lingüísticos dela advindos.

ABSTRACT: This paper emphasizes some aspects of the Brazilian Portuguese after the literary modernist revolution. It is said this literary moviment has changed.

8 Segundo Martinet (1993:61-62), a fonćtica e a fonologia são níveis cm que qualquer diferenciação linguística comega a se mostrar. Essa diferenciação, porém, fica comumente excluída da maioria dos comentários metalingüísticos produzidos por não-lingüistas, porque são transformações sutis, que normalmente passam despercebidas dos usuários. 
LEITE, Marli Quadros. A contribuição modernista parı a fixação da norma lingüística brasileira.

the linguistc norm by the orality engrossment and in order to prove this we've used. the melalinguistic lexls by Rubem Braga e Manuel Bandeira.

KEYWORDS: Brazilian Portuguese; metalanguage; linguistic norm; purism.

\section{BIBLIOGRAFIA}

Obras de Lingüística e Cramálica:

BARRETO, Mário (1954) Falos da língua Porluguesa. 2. ed. Rio de Janciro : Organização Simōes.

COSERIU, Eugenio (1979) Sincronia, Diacronia e História. Rio de Janeiro : Presença/EDUSP. (1992) A Língua Literária. In: Na Ponta da Língua, n 121, Rio de Janeiro, 16 de outubro de 1992 (Resumo da conferência proferida no Colóquio Internacional da Língua Portuguesa Literária. Liceu Literário Português, Rio de Janciro).

(1995) Competência Lingüistica. Madrid : Credos.

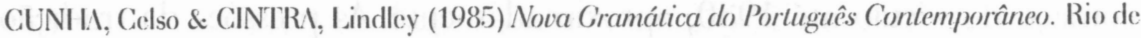
Janciro : Nova Fronteira.

PEREIRA, Eduardo Carlos (1945) Gramática Expositiva: curso superior. 65 ed. São Paulo.

ROCI IA I IMA, Carlos II. da (1969) Gramática Normativa da Língua Porluguesa. 14 ed. Rio de Janciro : Briguict.

Obras de Lileratura e Crílica Literária:

BARBOS^, Rui (1966) Escrilos e Discursos Selelos. 2 ed. São Paulo : Aguilar:

ARRICUCCI JR. Davi. (1988) Braga de Novo por Aqui. In: (org.) Os Melhores Contos

de Rubem Braga. 2. ed. São Paulo : Clobal.

BANDEIRム, Manuel (1986) Poesia Completa e Prosa. Rio de Janeiro : Aguilar:

BRAGA, Rubem.(1991) As Boas Coisas da Vida. 4 ed. Rio de Janeiro : Record.

(1993) 200 Crônicas Escolhidas. 9 ed. Rio de Janeiro : Record. 
Revista da ANP()LL, n" 4, p. 221-247, jan./jun. 1998

CANDIDO, Antonio.(1992) ^ Vida ao Rés-do-chão. In: ANDRADE, Carlos Drummond de et al. Para Costar de Ler. v.5 (Crônicas) São Paulo : Ática.

COUTINIIO, Arânio (1976) Introdução à Lileratura no Brasil. Rio de Janciro : Civilização Brasileira.

FARIA, João Roberto (1982) Mário de Andrade c a Questão da I Língua Brasileira. In: Essludos sobre o Modernismo. Curitiba : Criar:

I ACOMBE, Américo Jacobina (1966) Rui, Escritor: In: I.ACERDA, V. C. de. Rui Barbosa: escrilos e discurso selelos. Rio de Janciro : Aguilar:

MARTINET, André (1993) Función y Dinámica de las Lenguas. (Traduzido do francês Fonction ct Dynamique des Langues. Armand Colin Éditeur : 1989) Madrid : Credos.

MOISÉS, Massaud (1994) ^ Crônica. In: . A Criação Lilerária (prosa II). 15. ed. rev. e atual. São Paulo : Cultrix. 